\title{
Review
}

\section{Role of Oxidative DNA Damage in Dietary Carcinogenesis}

\author{
Yusuke Hiraku ${ }^{1}$, Mariko Murata ${ }^{1}$ and Shosuke Kawanishi ${ }^{1,2,3}$ \\ ${ }^{1}$ Department of Environmental and Molecular Medicine, Mie University Graduate School of Medicine, Mie, Japan, \\ ${ }^{2}$ Faculty of Health Science, Suzuka University of Medical Science, Mie, Japan
}

(Received September 11, 2006; Revised October 25, 2006; Accepted October 26, 2006)

\begin{abstract}
Dietary factors are implicated in approximately $35 \%$ of cancers attributed to environmental factors. Although an extremely wide variety of dietary factors are considered to contribute to carcinogenesis, its precise mechanism remains to be clarified. We focused on the role of oxidative DNA damage in carcinogenesis mediated by various dietary factors. We investigated the mechanism of oxidative DNA damage induced by a) amino acid metabolites, in relation to carcinogenesis caused by protein intake and amino acid imbalance, b) heterocyclic amines formed during cooking meat and fish, c) sugar and hyperglycemiarelated aldehydes, d) carcinogens contained in fermented foods, such as urethane, e) phytoestrogens including soy isoflavones, $f$ ) carcinogens in edible plants, such as caffeic acid and isothiocyanate, $g$ ) food additives, such as potassium bromate and benzoyl peroxide. These dietary factors and their metabolites induced metal-mediated oxidative damage to DNA in human cultured cells and ${ }^{32} \mathrm{P}$-labeled DNA fragments obtained from human cancer-relevant genes. On the basis of our results, it is concluded that polycyclic compounds, such as heterocyclic amines, can cause oxidative DNA damage, although they appear to mainly form DNA adduct. On the other hand, monocyclic and aliphatic compounds, such as amino acid metabolites and urethane, may mainly cause oxidative DNA damage whereas they do not appear to form DNA adduct. Soy isoflavones may cause carcinogenesis through initiation via oxidative DNA damage caused by their metabolites and promotion via cell proliferation induced by themselves. In this review, we discuss the role of oxidative DNA damage as the common mechanism of dietary carcinogenesis.
\end{abstract}

Key words: dietary factor, oxidative DNA damage, reactive oxygen species, DNA adduct, carcinogenesis

\section{Introduction}

The causal relationship between dietary factors and human cancers is substantial $(1,2)$. Dietary factors are implicated in approximately $35 \%$ of cancers attributed to environmental factors (3). Several possible mechanisms whereby dietary factors could be causally associated with induction of human cancer have been proposed. (i) Ingestion of carcinogens contained in food. Aflatoxin and other dietary contaminants are known to be carcinogens. (ii) Exogenous and en- dogenous production of carcinogens from dietary constituents. Heterocyclic amines are exogenously formed from amino acids and proteins during cooking meat and fish $(4,5)$. Carcinogens are also formed endogenously from dietary constituents. Carcinogenic nitrosamines are endogenously formed by the nitrosation of secondary amines via the reaction with nitrite. (iii) Alteration in metabolic activation of carcinogens. In some instances, as with ethanol, its cocarcinogenic effect is to enhance the production of neoplasia by a mechanism of the activation of carcinogens. (iv) Promoting agents to act on initiated cells. The most common mechanism of diet-associated carcinogenesis in the human is considered to be through the action of major dietary constituents such as fat, carbohydrate and protein, as promoting agents (3). However, although an extremely wide variety of dietary factors are likely to contribute to carcinogenesis, the precise mechanism of carcinogenesis remains to be clarified.

Reactive oxygen species (ROS) are known to be involved in various human diseases including cancer. ROS are capable of causing damage to various cellular constituents, such as nucleic acids, proteins and lipids, leading to carcinogenesis. Although numerous chemicals are considered to cause carcinogenesis via the formation of DNA adduct, oxidative DNA damage may serve as the common mechanism for carcinogenesis induced by a wide variety of dietary factors. We have investigated the mechanism of oxidative DNA damage induced by various dietary factors, including a) amino acid metabolites, in relation to carcinogenesis caused by protein intake and amino acid imbalance, b) heterocyclic amines formed during cooking meat and fish, c) sugar and hyperglycemia-related aldehydes, d) carcinogens contained in fermented foods, such as urethane, e) phytoestrogens including soy isoflavones, $\mathrm{f}$ ) carcinogens in edible plants, such as caffeic acid and isothiocyanate, g) food additives such as potassium bromate and ben-

${ }^{3}$ Correspondence to: Shosuke Kawanishi, Faculty of Health Science, Suzuka University of Medical Science, 1001-1 Kishioka, Suzuka, Mie 510-0293, Japan. Tel: +81-59-381-2388 -ex-204; Fax: +81-59-3812386, E-mail: kawanisi@suzuka-u.ac.jp 
Table 1. Mechanism of DNA damage induced by dietary factors

\begin{tabular}{|c|c|c|c|c|c|}
\hline \multirow{2}{*}{ Dietary factors } & \multirow{2}{*}{ Suspected carcinogens } & \multicolumn{2}{|c|}{ DNA damage } & \multirow{2}{*}{ Ames test } & \multirow{2}{*}{ Ref. No. } \\
\hline & & *Adduct & †Oxidation & & \\
\hline \multirow[t]{2}{*}{ Amino acid metabolites } & 3-Hydroxyanthranilic acid & - & + & $?$ & (22) \\
\hline & Homogentisic acid & - & + & + & (28) \\
\hline \multirow{3}{*}{ Heterocyclic amines } & PhIP & ++ & + & + & (46) \\
\hline & MeIQx & ++ & + & + & (57) \\
\hline & IQ & ++ & + & + & $(65)$ \\
\hline Sugar & Glyceraldehyde & + & + & $?$ & (68) \\
\hline Fermented foods & Urethane & - & + & - & (91) \\
\hline Phytoestogens & Genistein & - & + & - & (99) \\
\hline \multirow[t]{3}{*}{ Plant components } & Allyl isothiocyanate & - & + & - & (120) \\
\hline & Caffeic acid & - & + & - & (112) \\
\hline & 4-Hydrazinobenzoic acid & $+?$ & + & $?$ & $(102)$ \\
\hline \multirow{2}{*}{ Food additives } & Potassium bromate & - & + & + & (124) \\
\hline & Benzoyl peroxide & - & + & - & (125) \\
\hline
\end{tabular}

*Adduct: - , no evidence; + , limited evidence provided by only one report; ++ , sufficient evidence provided by two or more reports. †Oxidation: + , evidence provided by our study.

zoyl peroxide.

In our experiments, we used human cultured cells and ${ }^{32} \mathrm{P}$-labeled DNA fragments obtained from human cancer-relevant genes. The advantage of using ${ }^{32} \mathrm{P}$ labeled DNA fragments is that we can examine not only DNA-damaging abilities of test chemicals but also the site specificity of DNA damage. We have demonstrated that various chemicals induced double-base DNA damage at the $5^{\prime}$-ACG-3' sequence (damaged bases are underlined), complementary to a hot spot of the $p 53$ gene, in the presence of $20 \mu \mathrm{M} \mathrm{Cu}(\mathrm{II})$ (6). To examine cellular DNA damage, we treated cultured cells with test chemicals alone, because these chemicals are capable of causing DNA damage by mobilizing endogenous copper ions. Copper is an essential component of chromatin $(7,8)$. Normal plasma copper level in humans is approximately $20 \mu \mathrm{M}$ (9), and thus, the concentration of copper used in our cell-free system is physiologically relevant. On the basis of our results, we summarized the relative potential of each (suspected) dietary carcinogen to cause oxidative DNA damage and DNA adduct formation as shown in Table 1. In this review, we discuss the role of oxidative DNA damage as the common mechanism of carcinogenesis mediated by various dietary factors.

\section{Amino Acid Metabolites}

Epidemiological studies have suggested that high protein intake is a risk factor for several types of cancers, particularly colon, rectum and breast cancers (10). Significantly increased risks of renal cell cancer were observed with increasing consumption of high protein foods (11). An animal experiment has demonstrated that high protein intake enhanced the development of chemically-induced preneoplastic foci in the liver (12). Amino acid imbalance may participate in dietary carcinogenesis. Methionine deficiency is reported to lower the threshold of chemical-induced toxicity and increase the risk of carcinogenesis (13). In experimental animals, threonine-imbalanced diet (basal diet supplemented with branched-chain amino acids or indispensable amino acids, which enhances threonine catabolism) induced accumulation of its metabolite aminoacetone (14), which is capable of causing DNA damage (15). However, the mechanism of carcinogenesis mediated by protein intake remains to be clarified. One possible mechanism of carcinogenesis caused by protein intake is DNA damage induced by amino acid metabolites. Several amino acid metabolites are proposed to be mutagenic and carcinogenic. Therefore, we examined the mechanism of oxidative DNA damage induced by amino acid metabolites.

Tryptophan metabolites: Tryptophan is metabolized to 3-hydroxyanthranilic acid (3-HAA) and 3hydroxykynurenine (3-HKyn) as shown in Fig. 1A. These metabolites are carcinogenic to the bladder in mice $(16,17)$. Higher concentrations of these metabolites were detected in urines of the patients with bladder cancer than those of normal subjects (18). Therefore, the possibility that abnormal tryptophan metabolism in some patients with bladder cancer might be of causal significance of this disease has been discussed (19). Subcutaneous injection of these metabolites induces leukemia in mice (20). These metabolites are capable of causing chromatid breakage and translocations in mammalian cells (21). We examined the mechanism of DNA damage induced by 3-HAA and 3-HKyn. These tryptophan metabolites induced DNA double-strand breaks in cultured human cells in the presence of Mn(II). The enhancing effect of a catalase inhibitor and the inhibitory effect of $o$-phenanthroline on the strand 
A
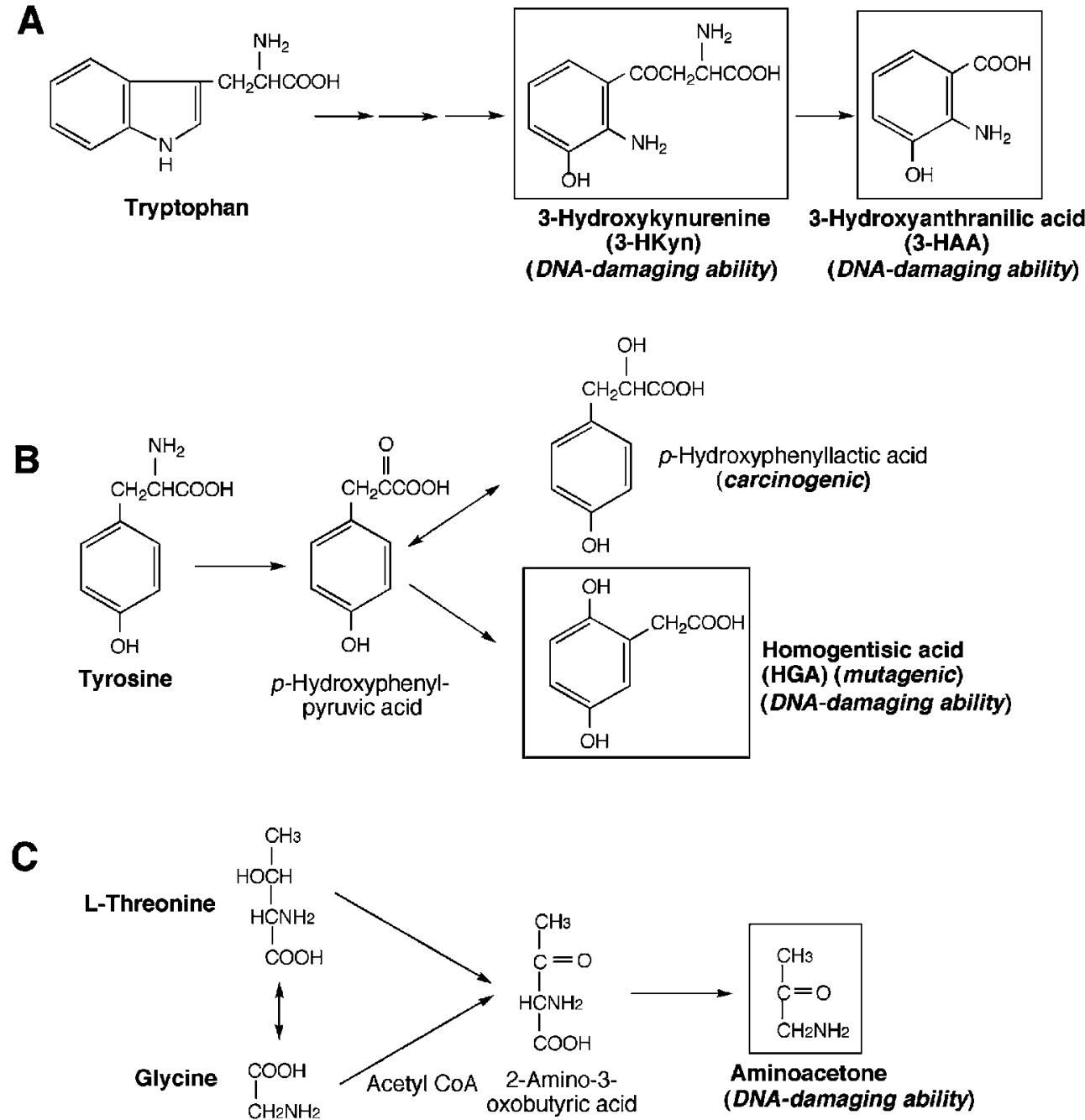

Fig. 1. Metabolism of amino acids (tryptophan, tyrosine and threonine).

breaks indicated the involvement of $\mathrm{H}_{2} \mathrm{O}_{2}$ and endogenous metal ion. These metabolites induced damage to DNA fragments obtained from c-Ha-ras-1 protooncogene in the presence of $20 \mu \mathrm{M} \mathrm{Cu}$ (II). The inhibitory effects of bathocuproine, a $\mathrm{Cu}(\mathrm{I})$-chelating agent, and catalase on DNA damage suggest involvement of $\mathrm{Cu}(\mathrm{I})$ and $\mathrm{H}_{2} \mathrm{O}_{2} . \mathrm{Cu}(\mathrm{II})$-mediated DNA damage was enhanced by preincubation of 3-HAA with Mn(II). These results suggest that in the presence of $\mathrm{Mn}(\mathrm{II})$ or $\mathrm{Cu}(\mathrm{II})$, these tryptophan metabolites produce $\mathrm{H}_{2} \mathrm{O}_{2}$, which is activated by transition metal ion to cause oxidative DNA damage (22).

Tyrosine metabolites: Certain metabolites of tyrosine have been reported to be carcinogenic or mutagenic. Tyrosine is metabolized to homogentisic acid (HGA) and $p$-hydroxyphenyllactic acid (Fig. 1B). $p$-Hydroxyphenyllactic acid caused leukemic changes and hepatomas in mice $(23,24)$. HGA is accumulated and high incidence of hepatocarcinoma occurs in patients with chronic form of hereditary tyrosinemia $(23,25)$. Recently, it has been reported that chronic liver disease in murine hereditary tyrosinemia type 1 induces resistance to cell death, which may lead to an accumulation of damaged cells and therefore enhance the risk for cancer (26). HGA has been reported to be mutagenic in Salmonella typhimurium and Chinese hamster V79 cells (27). Thus, HGA and its metabolites may be involved in carcinogenesis. We demonstrated that HGA caused damage to DNA fragments in the presence of $\mathrm{Cu}(\mathrm{II})$. DNA damage was enhanced by piperidine treatment, suggesting that HGA plus $\mathrm{Cu}(\mathrm{II})$ caused not only strand breakage but also base damage and liberation. Catalase and bathocuproine inhibited DNA damage, suggesting the involvement of $\mathrm{H}_{2} \mathrm{O}_{2}$ and $\mathrm{Cu}(\mathrm{I})$. The formation of 8-oxo-7,8-dihydro-2'-deoxyguanosine (8-oxodG) by HGA increased depending on its concentration in the presence of $20 \mu \mathrm{M} \mathrm{Cu}(\mathrm{II})$. It is concluded that $\mathrm{H}_{2} \mathrm{O}_{2}$ is generated during $\mathrm{Cu}(\mathrm{II})$-catalyzed HGA autoxidation 
and reacts with $\mathrm{Cu}(\mathrm{I})$ to form the $\mathrm{Cu}(\mathrm{I})$-peroxide complex, capable of causing oxidative DNA damage (28).

Threonine and glycine metabolites: Aminoacetone is an aminoketone, which is produced through oxidation of L-threonine or condensation of glycine and acetyl coenzyme A (Fig. 1C) (29). L-Threonine administration significantly increased urinary excretion of aminoacetone in humans (29). Consumption of threonine-imbalanced diet resulted in aminoacetone accumulation in experimental animals (14). Serum amino acid profiles are associated with malignant tumors. It has been reported that cancer patients had significantly decreased serum levels of threonine and glycine compared with the control group $(30,31)$. The level of aminoacetone in tumor tissues was higher than that in normal tissues (32). These findings suggest that accumulation of aminoacetone caused by enhanced catabolism of threonine and glycine may contribute to carcinogenesis. In our study, aminoacetone caused DNA cleavage and 8-oxodG formation in human cultured cells. Aminoacetone caused damage to DNA fragments obtained from the human c-Ha-ras- 1 and $p 53$ genes in the presence of $\mathrm{Cu}(\mathrm{II})$. Analysis of the products generated from aminoacetone revealed that aminoacetone underwent $\mathrm{Cu}(\mathrm{II})$-mediated autoxidation in two different pathways: the major pathway in which methylglyoxal and $\mathrm{NH}_{4}{ }^{+}$are generated and the minor pathway in which 2,5-dimethylpyrazine is formed through condensation of two molecules of aminoacetone. These findings suggest that $\mathrm{H}_{2} \mathrm{O}_{2}$ generated during the autoxidation of aminoacetone reacts with $\mathrm{Cu}(\mathrm{I})$ to form reactive species capable of causing oxidative DNA damage (15).

We have demonstrated that various amino acid metabolites induce oxidative DNA damage mediated by endogenous metal ions. On the basis of these findings, it is concluded that oxidative DNA damage caused by amino acid metabolites may be involved in carcinogenesis induced by protein intake and amino acid imbalance.

\section{Heterocyclic Amines}

Heterocyclic amines are a family of mutagenic and carcinogenic compounds produced during pyrolysis of creatine, proteins and amino acids (4,5,33-35). Heterocyclic amines, such as 2-amino-1-methyl-6phenylimidazo $[4,5-b]$ pyridine (PhIP), 2-amino-3,8dimethylimidazo[4,5- $f$ ]quinoxaline (MeIQx) and 2amino-3-methylimidazo[4,5-f]quinoline (IQ), have been isolated from cooked beef, chicken, fish and pork $(4,5,33,36)$. An epidemiological study showed a significantly increased risk for cancers at all sites and for gastric cancer associated with the consumption of cooked fish (4). Thus, most heterocyclic amines in foodpyrolysates were suggested to pose probable or possible carcinogenic risk to humans (4).

Sugimura and coworkers have extensively investigated the mechanism of carcinogenesis induced by heterocyclic amines. DNA adduct formation has been considered to be a major causal factor of DNA damage by carcinogenic heterocyclic amines. However, Hayatsu and coworkers have demonstrated that an $N$-hydroxy derivative of 3-amino-1-methyl-5H-pyrido[4,3-b]indole (Trp-P-2) produces intracellular reactive oxygen species that can damage DNA in cultured cells $(37,38)$. These reports led us to the idea that DNA adduct formation may not be sufficient for heterocyclic amine-induced carcinogenesis, and that ROS may participate in this process. Details of our studies on oxidative DNA damage induced by heterocyclic amines and their metabolites are described below.

PhIP: In investigations of foods for the presence of multiple heterocyclic amines, PhIP is usually found to be the most abundant. Oral administration of PhIP produces lymphomas in mice (39), adenocarcinomas of the small and large intestine, and mammary adenocarcinomas in rats (40). Thus, PhIP has been estimated to possess possible carcinogenic risk to humans (Group 2B) by International Agency for Research on Cancer (IARC) (4). Heterocyclic amines are metabolically activated to DNA-binding products via the exocyclic amino group. PhIP is oxidized to a $N$-hydroxy derivative $[\mathrm{PhIP}(\mathrm{NHOH})]$ in the liver by cytochrome $\mathrm{P} 450$ enzymes, and the latter is esterified by acetyltransferases or sulfotransferases to its ultimate carcinogen $(4,5,36)$. The DNA-adduct formation is thought to be crucially important in carcinogenesis and PhIP-DNA adducts have been detected in human tissues (36). However, there are several reports indicating no straightforward relationship between PhIP-DNA adduct formation and carcinogenicity (41-43). It has been reported that oral administration of PhIP to rats increased 8-oxodG level in mammary gland (44). Furthermore, it has been reported that several antioxidants significantly inhibited PhIP-induced mutagenicity (45) and carcinogenicity (41), suggesting involvement of ROS.

We demonstrated that $\mathrm{PhIP}(\mathrm{NHOH})$ induced $\mathrm{Cu}(\mathrm{II})$ dependent 8-oxodG formation, which was enhanced by addition of NADH. Experiments with ${ }^{32} \mathrm{P}$-labeled DNA fragments showed that $\mathrm{PhIP}(\mathrm{NHOH})$ formed formamidopyrimidine-DNA glycosylase (Fpg)-sensitive and piperidine-labile lesions at the $5^{\prime}$-site guanine of GG and GGG sequences. Interestingly, the antioxidant enzyme superoxide dismutase (SOD) enhanced the formation of piperidine-labile lesions at thymine residues. A UV-visible spectroscopic study indicated that $\mathrm{Cu}(\mathrm{II})$ and $\mathrm{SOD}$ catalyze the autoxidation of $\mathrm{PhIP}(\mathrm{NHOH})$. These results suggest that $\mathrm{Cu}(\mathrm{II})$-dependent autooxidation of $\mathrm{PhIP}(\mathrm{NHOH})$ coupled with 


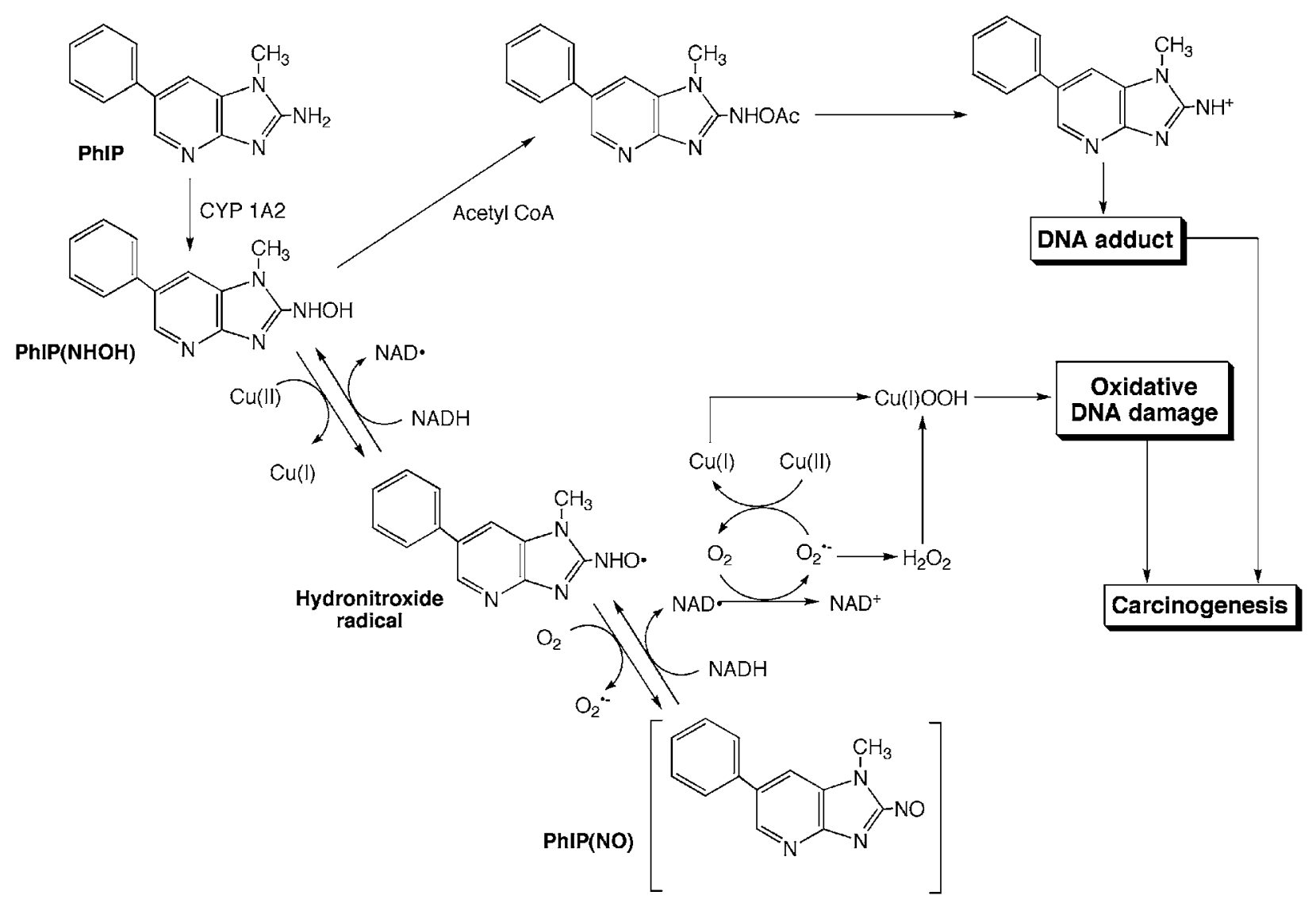

Fig. 2. DNA adduct formation and oxidative DNA damage induced by PhIP.

NADH-mediated reduction of its oxidized product forms redox cycle, resulting in oxidative DNA damage (46) in addition to DNA adduct formation (Fig. 2).

MelQx: Oral administration of MeIQx produces hepatocellular carcinomas and lung tumors in mice $(47,48)$, and hepatocellular carcinomas and squamous cell carcinomas of the Zymbal gland in rats $(49,50)$. MeIQx is oxidized to the $N$-hydroxy derivative $[\mathrm{MeIQx}(\mathrm{NHOH})]$ in the liver by cytochrome P450 1A2 isozyme, and the latter is esterified by $O$-acetyltransferase to the $N$-acetoxy derivative, which reacts with DNA to form adducts $(51,52)$. DNA adducts generated by MeIQx were found in vitro and in vivo by means of the ${ }^{32} \mathrm{P}$-postlabeling method (53). On the other hand, it has been reported that several antioxidants significantly inhibited MeIQx-induced hepatocarcinogenesis in rats $(54,55)$. 8-oxodG level in rat liver increased dose-dependently with the concentration of MeIQx in the diet (56). These reports lead us to consider that reactive oxygen species may participate in MeIQx-induced carcinogenesis.

In our study, MeIQx(NHOH) caused $\mathrm{Cu}(\mathrm{II})$-mediated DNA damage, including 8-oxodG formation, and DNA damage was greatly enhanced by NADH. A UVvisible spectroscopic study showed that rapid decompo- sition of MeIQx $(\mathrm{NHOH})$ occurred in the presence of $\mathrm{Cu}(\mathrm{II})$, suggesting that $\mathrm{Cu}(\mathrm{II})$ catalyzes the autoxidation of MeIQx(NHOH) and NADH reduces the oxidized product back to MeIQx(NHOH). These results suggest that a copper-peroxo intermediate, derived from the reaction of $\mathrm{Cu}(\mathrm{I})$ with $\mathrm{H}_{2} \mathrm{O}_{2}$, participates in DNA damage by MeIQx $(\mathrm{NHOH})$, and $\mathrm{NADH}$ enhances DNA damage via a redox cycle (57).

IO: IQ is a representative member of mutagenic and carcinogenic heterocyclic amines. 2-Nitro-3-methylimidazo[4,5- $f$ ]quinoline (nitro-IQ) is an analogue of IQ with a nitro group in place of the amino group and detected in urine as an IQ metabolite (34). IQ is chemically converted to nitro-IQ by treatment with nitrite (58). Exposure to sunlight causes oxidation of IQ to form nitro-IQ (59). Thus, nitro-IQ may be present by photoactivation in airborne particles from cigarette smoke and frying meat, and humans are likely to be exposed to nitro-IQ. Nitro-IQ exhibits mutagenicity in bacterial systems (60-62) and genotoxic activities $(63,64)$, as well as IQ.

We have found that nitro-IQ caused DNA damage including 8-oxodG formation in the presence of NADH and $\mathrm{Cu}(\mathrm{II})$. Catalase and bathocuproine inhibited DNA damage, suggesting the involvement of $\mathrm{H}_{2} \mathrm{O}_{2}$ and $\mathrm{Cu}(\mathrm{I})$. 
A UV-vis spectroscopic study showed that rapid spectral change was observed in the presence of $\mathrm{Cu}(\mathrm{II})$. These results suggest that nitro-IQ is reduced nonenzymatically by $\mathrm{NADH}$ in the presence of $\mathrm{Cu}$ (II) to form the redox reaction, resulting in oxidative DNA damage mediated by the copper-oxygen complex derived from $\mathrm{Cu}(\mathrm{I})$ and $\mathrm{H}_{2} \mathrm{O}_{2}$. We conclude that nonenzymatic reduction of nitro-IQ and resulting oxidative DNA damage can play a role in carcinogenesis of IQ (65).

We demonstrated that heterocyclic amines and their metabolites cause oxidative DNA damage. On the basis of these findings, it is concluded that oxidative DNA damage may be involved in the carcinogenic process of heterocyclic amines in addition to DNA adduct formation.

\section{Sugar}

Epidemiological and experimental studies show that diets high in refined sugars possibly increase the risk of colorectal cancer (66). Moreover, a link between sugar consumption and pancreatic carcinoma has been suggested (66). A frequent consumption of sugars may lead to insulin resistance, and cause an increase in insulinlike growth factors (IGF), which are promoters of carcinogenesis. Increased risks of cancers and oxidative DNA damage have been observed in diabetic patients (67). Many endogenous aldehydes such as 3-deoxyglucosone and glyceraldehyde increase under hyperglycemic condition. We demonstrated that these endogenous aldehydes induced oxidative DNA damage as described below, and postulated that this type of DNA damage participates in diabetes-associated carcinogenesis (68) in addition to IGF-mediated tumor promotion. Our experiments with ${ }^{32} \mathrm{P}-5^{\prime}$-end-labeled DNA fragments showed that these aldehydes induced $\mathrm{Cu}$ (II)-mediated DNA damage, which was enhanced by the addition of $\mathrm{H}_{2} \mathrm{O}_{2}$. Glyceraldehyde significantly increased 8-oxodG formation in human HL-60 cultured cells, and the addition of glucose oxidase, as an $\mathrm{H}_{2} \mathrm{O}_{2}$ generating system, significantly increased 8-oxodG formation. We conclude that oxidative DNA damage by hyperglycemia-related aldehydes, especially glyceraldehyde, and marked enhancement by $\mathrm{H}_{2} \mathrm{O}_{2}$ may participate in diabetes-associated carcinogenesis, with reference to high sugar intake.

\section{Alcohol and Carcinogens in Fermented Foods}

Alcohol drinking was classified as carcinogenic to humans (Group 1) by IARC on the basis of sufficient epidemiological evidence (69). The occurrence of malignant tumors of the oral cavity, pharynx, larynx, esophagus and liver is causally related to the consumption of alcoholic beverages (70). IARC evaluated acetaldehyde, the major intermediary metabolite of ethanol, as possibly carcinogenic to humans (Group 2B)
(71). Acetaldehyde reacts with DNA to form DNA adducts, such as $1, N^{2}$-propano-2'-deoxyguanosine, which is formed in the presence of histones and other basic molecules. This adduct can exist as a ring-closed or ring-opened aldehyde form. Whereas the ring-closed form is mutagenic, the ring-opened form can participate in the formation of DNA-protein and DNA interstrand cross-links (72). In addition, acetoaldehyde can inhibit DNA repair. It has been reported that various aldehydes inhibit $O^{6}$-methylguanine-DNA methyltransferase (MGMT) in cultured human cells (73), and that an intraperitoneal injection of ethanol inhibited the activity of MGMT in rats (74). On the other hand, alcohol also induces oxidative stress, leading to oxidative DNA damage, lipid peroxidation, protein carbonyl formation, and the decrease in hepatic antioxidant defense $(75,76)$, which may participate in carcinogenesis. Ethanol increased the formation of 8-oxodG in human mammary epithelial cells (77). Trans-4-hydroxy-2nonenal, a product of lipid peroxidation, is known to react with DNA to form promutagenic etheno-DNA adducts (78). In addition, CYP2E1 is inducible by ethanol, and ethanol exerts an enhancing effect on metabolic activation by CYP2E1 of procarcinogens, such as nitrosoamines $(75,79)$. Therefore, ethanol may exhibit a cocarcinogenic effect by enhancing the production of ultimate carcinogens via metabolic activation.

Urethane (ethyl carbamate) is produced by chemical reaction of urea and ethanol present in wine and sake, when these beverages are heated under the acidic conditions of fermentation (80). Urethane is also present in fermented food products such as bread, yogurt, and cheese (81-83). In rodents, urethane is a multipotential animal carcinogen, producing lung tumors, lymphomas, hepatomas, and melanomas $(84,85)$ and thus evaluated as a Group $2 \mathrm{~B}$ carcinogen by IARC (85). The genotoxic effects of urethane, however, remain unclear as in vitro mutagenesis studies, such as the Ames test (86). Urethane has been reported to form DNA adducts in the liver of rats and mice (87-89). Methyl carbamate, structurally analogous to urethane, is carcinogenic to rats (90), although it can not form DNA adduct. Thus, we investigated whether urethane metabolites can induce oxidative DNA damage.

We have shown that $N$-hydroxyurethane, a urethane metabolite, induced damage to ${ }^{32} \mathrm{P}$-labeled DNA fragments and 8-oxodG formation in the presence of $\mathrm{Cu}(\mathrm{II})$. DNA damage was inhibited by catalase and bathocuproine, suggesting the involvement of $\mathrm{H}_{2} \mathrm{O}_{2}$ and $\mathrm{Cu}(\mathrm{I})$. When treated with esterase, $N$-hydroxyurethane induced 8-oxodG formation to a similar extent as that induced by hydroxylamine, which is generated by treatment of $N$-hydroxyurethane with esterase (Fig. 3). Enhancement of DNA cleavages by endonuclease IV suggests that hydroxylamine induced depurination. 


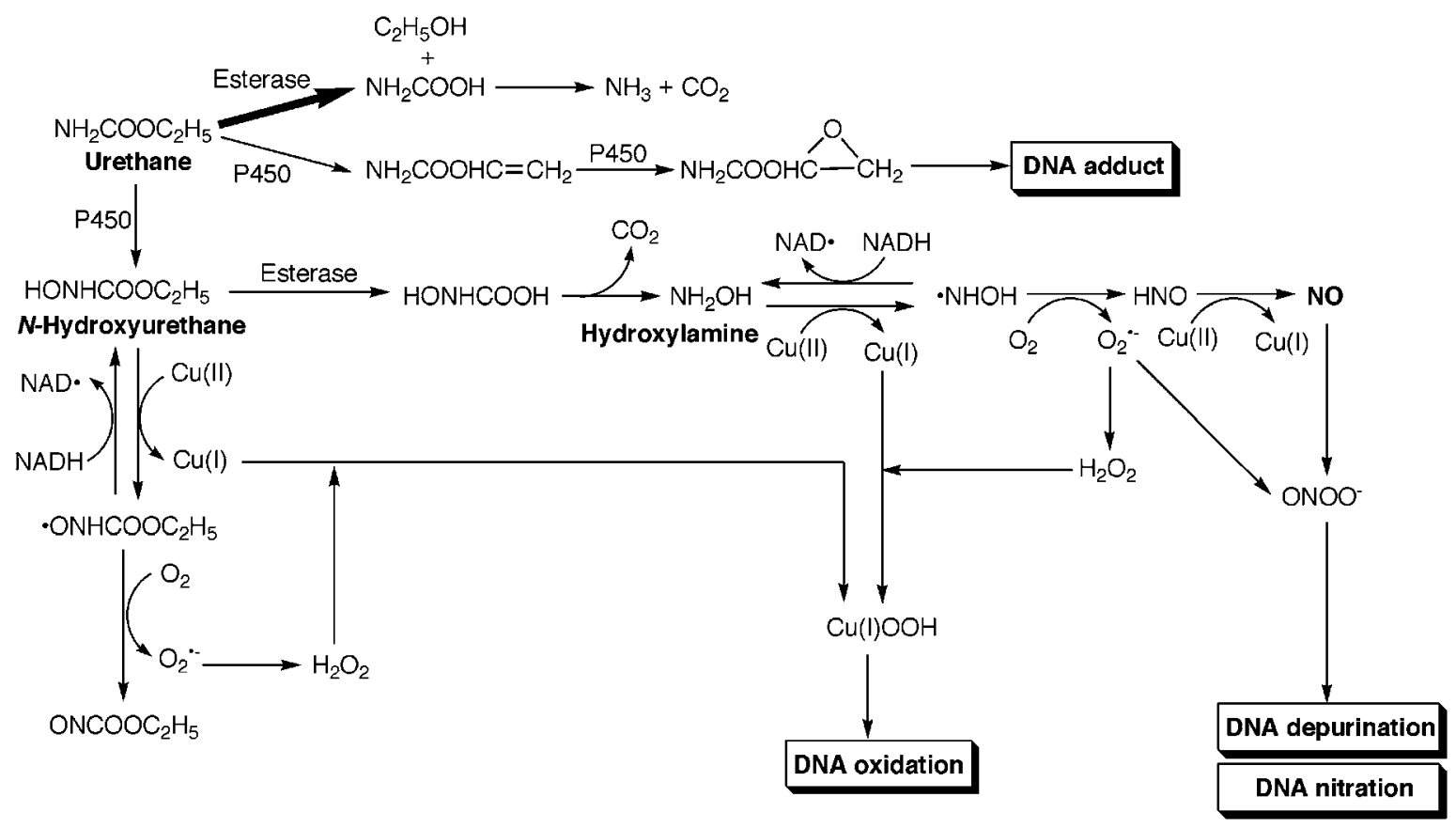

Fig. 3. Proposed mechanisms of DNA damage induced by urethane metabolites.

Furthermore, hydroxylamine induced a significant increase in 8-oxodG formation in HL-60 cells but not in its $\mathrm{H}_{2} \mathrm{O}_{2}$-resistant clone HP 100 cells. Interestingly, electron spin resonance (ESR) spectroscopy, utilizing $\mathrm{Fe}[\mathrm{N} \text {-(dithiocarboxy)sarcosine }]_{3}$, demonstrated that nitric oxide (NO) was generated from hydroxylamine and esterase-treated $N$-hydroxyurethane. In conclusion, urethane may induce carcinogenesis through oxidative DNA damage and, to a lesser extent, NO-mediated DNA depurination by its metabolites, in addition to DNA adduct formation (Fig. 3) (91).

\section{Phytoestrogens}

Epidemiological and experimental studies have shown that soy products can reduce the risk of cancer $(92,93)$ and provide other benefits. The soy isoflavones, genistein $\left(5,7,4^{\prime}\right.$-trihydroxyisoflavone) and daidzein ( $7,4^{\prime}$-dihydroxyisoflavone), are representative phytoestrogens (94) and act as chemopreventive agents against cancers, cardiovascular disease, and osteoporosis. However, recent studies revealed that genistein and/or daidzein induced cancer of reproductive organs in rodents, such as the uterus (95) and vulva (96). Genistein also has an enhancing effect on breast (97) and colon cancer (98). These reports led us to consider that soy isoflavones may have a carcinogenic effect on female reproductive organs.

To clarify the molecular mechanisms of carcinogenesis by soy isoflavones, we examined the ability of genistein, daidzein, and their metabolites, 5,7,3', $4^{\prime}$ tetrahydroxyisoflavone (orobol), 7, $3^{\prime}, 4^{\prime}$-trihydrox- yisoflavone $\left(7,3^{\prime}, 4^{\prime}\right.$-OH-IF), and $6,7,4^{\prime}$-trihydroxyisoflavone $\left(6,7,4^{\prime}-\mathrm{OH}-\mathrm{IF}\right)$, to induce DNA damage and cell proliferation (99). We performed the E-SCREEN assay to examine the estrogenic activity of these soy isoflavones and their metabolites by comparing the number of estrogen-dependent human breast cancer cell line, MCF-7 cells, in the absence of estrogens (negative control) and in the presence of these compounds (100). This assay revealed that genistein and daidzein enhanced proliferation of MCF-7 cells, while their metabolites had little or no effect. A surface plasmon resonance sensor showed that binding of isoflavoneliganded estrogen receptors (ER) to estrogen response elements (ERE) was largely consistent with cell proliferative activity of isoflavones. Orobol and 7,3', $4^{\prime}-\mathrm{OH}$-IF significantly increased 8-oxodG formation in human mammary epithelial MCF-10A cells, while genistein, daidzein, and 6,7,4'-OH-IF did not. Experiments using isolated DNA revealed that metal-dependent oxidative DNA damage was induced by orobol and $7,3^{\prime}, 4^{\prime}-\mathrm{OH}-$ IF. DNA damage was enhanced by the addition of NADH. These findings suggest that oxidative DNA damage by isoflavone metabolites plays a role in tumor initiation and that cell proliferation by isoflavones via ER-ERE binding induces tumor promotion and/or progression, resulting in cancer of estrogen-sensitive organs (Fig. 4) (99). Our results suggest that soy isoflavones, genistein and daidzein, have the ability to produce not only beneficial actions but also adverse effects including carcinogenesis in a similar manner to estrogens (101). 


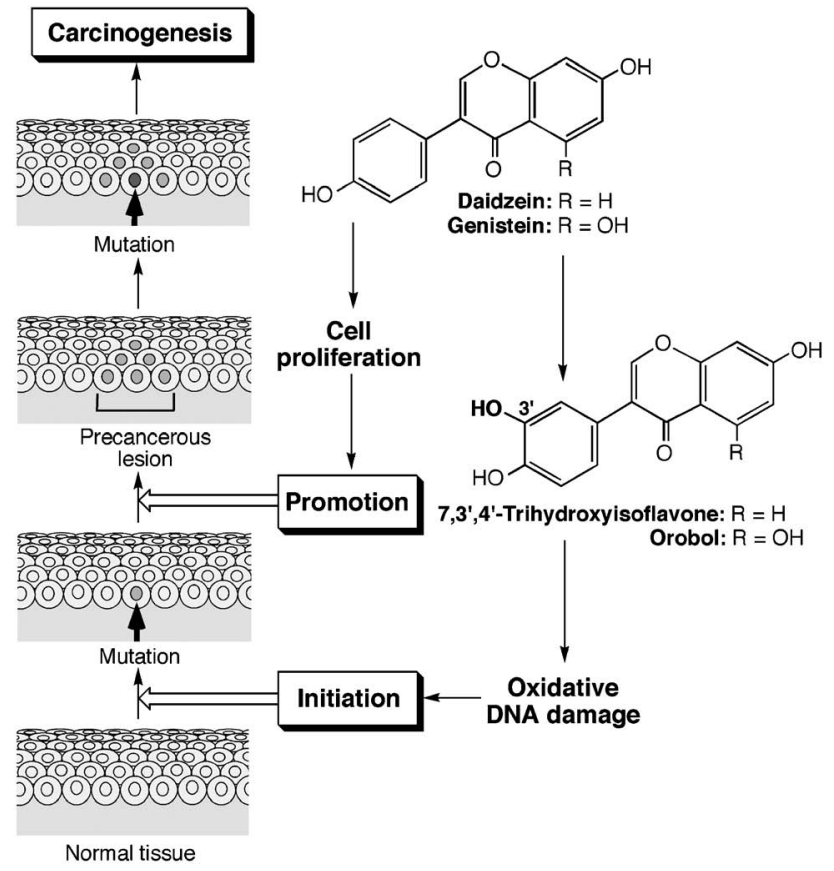

Fig. 4. Proposed mechanisms of carcinogenesis induced by soy isoflavones.

\section{Carcinogens in Edible Plants}

Some naturally occurring substances in edible plants are carcinogenic. For example, cycasin in cycad and ptaquiloside in bracken are such compounds. 4Hydrazinobenzoic acid contained in the mushroom Agaricus bisporus is also carcinogenic. We demonstrated that 4-hydrazinobenzoic acid induced DNA damage via not only $\mathrm{H}_{2} \mathrm{O}_{2}$ production but also phenyl radical production, suggesting that both oxidative DNA damage and DNA adduct formation play important roles in carcinogenesis (102). On the other hand, epidemiological studies have shown a marked reduction in the risk of developing a variety of malignancies by large consumption of vegetables and fruits $(103,104)$. However, the supplementation with $\beta$-carotene and/or vitamin $\mathrm{A}$ to smokers and asbestos-exposed workers increased the incidence of lung cancer $(105,106)$. We have demonstrated that several phytochemicals, known as antioxidants such as $\beta$-carotene and $\alpha$-tocopherol, induced oxidative DNA damage due to their prooxidant properties (107-109). We examined the mechanisms of DNA damage induced by carcinogens in edible plants, which have antioxidant properties, such as caffeic acid and isothioocyanates.

Caffeic acid: Coffee is evaluated as possibly carcinogenic to the human urinary bladder (Group 2B) whereas there is some evidence of an inverse relationship between coffee drinking and cancer of the large bowel (110). Caffeic acid is one of the coffee polyphenols, which have antioxidant properties. Oral ad- ministration of caffeic acid in combination with known carcinogens resulted in enhancing or inhibiting effects (111). We found that caffeic acid induced alkali-labile DNA strand breaks in cultured human cells in the presence of $\mathrm{Mn}$ (II). The strand breakage was increased by the treatment with buthionine sulphoximine (a GSH synthesis inhibitor) and 3-aminotriazol (a catalase inhibitor), indicating the involvement of $\mathrm{H}_{2} \mathrm{O}_{2}$. Experiments with isolated DNA showed that caffeic acid caused DNA damage in the presence of $\mathrm{Cu}(\mathrm{II}) . \mathrm{Cu}(\mathrm{II})$ mediated DNA damage was enhanced by preincubation of caffeic acid with $\mathrm{Mn}$ (II). We suggested that caffeic acid produced $\mathrm{H}_{2} \mathrm{O}_{2}$ in the presence of $\mathrm{Mn}$ (II) or $\mathrm{Cu}$ (II) to cause damage to cellular and isolated DNA (112).

Isothiocyanates: Organic isothiocyanates $(\mathrm{R}-\mathrm{N}=$ $\mathrm{C}=\mathrm{S}$ ) are widely distributed in plants, many of which are consumed by humans. Vegetables, including broccoli and cauliflower, contain substantial quantities of isothiocyanates, mostly in the form of their glucosinolate precursors (113). Several studies revealed that preventive effects of isothiocyanates against chemical carcinogen-induced carcinogenesis in vivo and in vitro (114-116). On the other hand, it has been proposed that isothiocyanates exhibit carcinogenic potential to humans. The National Toxicology Program (NTP) has evaluated that allyl isothiocyanate (AITC) is carcinogenic to rats (117). AITC caused transitional-cell papillomas in the urinary bladder of male rats, and fibrosarcomas in the subcutaneous tissue in female rats (117). Benzyl isothiocyanate (BITC) and phenethyl isothiocyanate (PEITC) exhibited promotion potential during the postinitiation stage $(118,119)$. We demonstrated that AITC caused $\mathrm{Cu}(\mathrm{II})$-mediated DNA damage and 8oxodG formation more strongly than BITC and PEITC. AITC significantly induced 8-oxodG formation in HL-60 cells, but not in $\mathrm{H}_{2} \mathrm{O}_{2}$-resistant $\mathrm{HP} 100$ cells, suggesting the involvement of $\mathrm{H}_{2} \mathrm{O}_{2}$ in DNA damage. A UV-visible spectroscopic study revealed an association between the generation of superoxide and the yield of $\mathrm{SH}$ group from isothiocyanates. We conclude that oxidative DNA damage may play important roles in carcinogenic processes induced by AITC (120).

Sulforaphane (4-methylsulfinylbutyl isothiocyanate) and other isothiocyanates are thought to exhibit an anticarcinogenic effect by inducing Phase II metabolizing enzymes and antioxidant enzymes through the activation of the transcription factor Nrf2 $(121,122)$. On the other hand, we have demonstrated that isothiocyanates are capable of causing oxidative DNA damage, although isothiocyanates with a long chain have a weaker ability to produce $\mathrm{SH}$ group compared with AITC. If their DNA-damaging ability exceeds the anticarcinogenic effect, they would exhibit a carcinogenic potential. Proposed mechanism of carcinogenesis induced by isothiocyanates is shown in Fig. 5. 


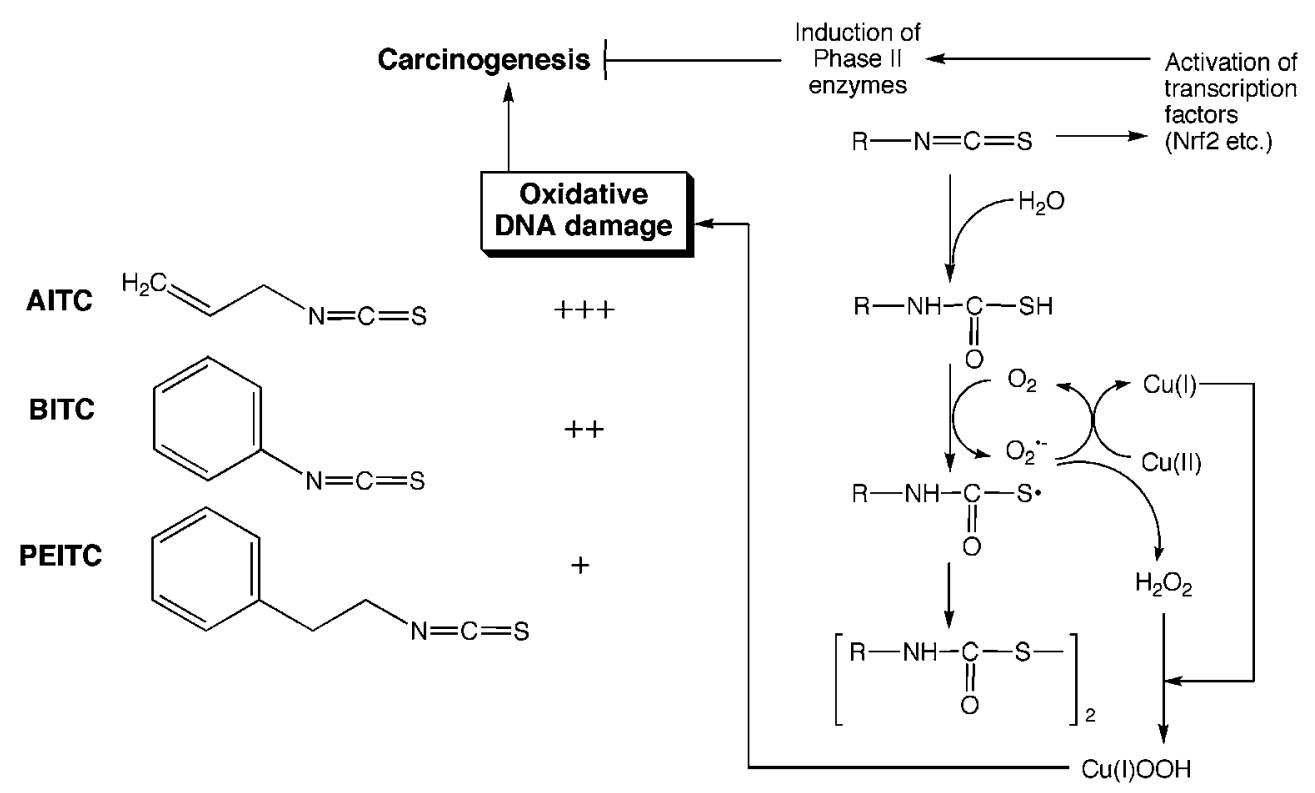

Fig. 5. Proposed mechanisms of induction and suppression of carcinogenesis by isothiocyanates.

\section{Food Additives}

Most manufactured foods and drinks contain chemicals that added deliberately with the intention to have certain functions, such as preservatives, colors, flavors and antioxidants. Experimental evidence has shown that some food additives are mutagenic or carcinogenic.

Potassium bromate: Potassium bromate $\left(\mathrm{KBrO}_{3}\right)$ is allowed only for bread baking as a food additive because of its oxidizing property, and should not be detected in the final food products. $\mathrm{KBrO}_{3}$ is potentially mutagenic and a well-known renal carcinogen to rats (123). Our previous study indicated that $\mathrm{KBrO}_{3}$ induced 8-oxodG formation in human leukemia cell line HL-60 as well as in its $\mathrm{H}_{2} \mathrm{O}_{2}$-resistant clone, $\mathrm{HP} 100$, suggesting no involvement of $\mathrm{H}_{2} \mathrm{O}_{2}$ (124). Depletion of GSH by buthionine sulfoximine (BSO) had a little inhibitory effect on $\mathrm{KBrO}_{3}$-induced 8-oxodG formation, because of the presence of cysteine. Experiments with ${ }^{32} \mathrm{P}$ labeled DNA fragments obtained from the human cancer-relevant genes suggested that $\mathrm{KBrO}_{3}$ induced 8oxodG formation at 5 -site guanine of GG and GGG sequences of double-stranded DNA in the presence of GSH, since the treatment with Fpg protein led to chain cleavages at the guanine residues. $\mathrm{KBrO}_{3}$ required glutathione and cysteine in guanine-specific oxidation of DNA. It is speculated that reduction of $\mathrm{KBrO}_{3}$ by $\mathrm{SH}$ compounds yields bromine oxides and bromine radicals, which cause guanine oxidation, leading to carcinogenesis of $\mathrm{KBrO}_{3}$.

Benzoyl peroxide: Benzoyl peroxide (BzPO), a free-radical generator, has a tumor-promoting activity. $\mathrm{BzPO}$ is widely used in variety of applications, including a food additive. BzPO induced piperidine-labile sites at the $5^{\prime}$-site guanine of GG and GGG sequences of double-stranded DNA in the presence of $\mathrm{Cu}(\mathrm{I})$ (125). BzPO plus $\mathrm{Cu}(\mathrm{I})$ induced 8-oxodG formation in doublestranded DNA more effectively than that in singlestranded DNA. Furthermore, we observed that BzPO increased the amount of 8-oxodG in human cultured cells. It is concluded that benzoyloxyl radicals generated by the reaction of $\mathrm{BzPO}$ with $\mathrm{Cu}(\mathrm{I})$ may lead to 8oxodG formation and piperidine-labile oxidative lesions at the $5^{\prime}$-guanine of consecutive guanine sequences in double-stranded DNA, and the damage seems to be relevant to the tumor-promoting activity of BzPO.

\section{Conclusion}

We have investigated the mechanism of DNA damage induced by various dietary factors. We summarized the mechanism of DNA damage induced by dietary factors (Table 1). Polycyclic compounds, including heterocyclic amines, are likely to mainly form DNA adduct, whereas they can cause oxidative DNA damage. On the other hand, monocyclic and aliphatic compounds, including amino acid metabolites and urethane, mainly cause oxidative DNA damage whereas these metabolites do not appear to form DNA adduct.

ROS are considered to play an important role in carcinogenesis through oxidative DNA damage (126). ROS can induce the formation of various oxidative DNA lesions (127-130). Guanine is most easily oxidized among the four DNA bases, because the oxidation potential of guanine is lower than the other three DNA bases, adenine, cytosine and thymine $(129,131)$. 8oxodG is considered to be a mutagenic DNA lesion. It was reported that misincorporation of adenine occurs 
opposite 8-oxodG during DNA synthesis, leading to $\mathrm{G} \rightarrow \mathrm{T}$ transversions $(132,133)$. The mutational spectra induced by other oxidative DNA lesions have been investigated. 2,5-Diamino-4H-imidazol-4-one (Iz) and 2,2,4-triamino-5- $(2 H)$-oxazolone $(\mathrm{Oz})$ can be generated by oxidation of guanine and 8-oxodG (129). Similarly to 8-oxodG, Oz induced $\mathrm{G} \rightarrow \mathrm{T}$ transversions (134), whereas Iz induced $G \rightarrow C$ transversions $(135,136)$.

We demonstrated that various dietary factors caused metal-mediated oxidative DNA damage. On the basis of our results, oxidative DNA damage may serve as a common mechanism of carcinogenesis mediated by various dietary factors. On the other hand, some dietary carcinogens are known to form DNA adduct. Each carcinogen forms characteristic DNA adduct with different nature and mutagenic potential (137). Thus, dietary factors may participate in carcinogenesis via DNA adduct formation as a specific mechanism in cooperation with oxidative DNA damage as a common mechanism. These studies would provide an insight in the mechanism of dietary carcinogenesis and its prevention.

\section{References}

1 Doll R, Peto R. The causes of cancer: quantitative estimates of avoidable risks of cancer in the United States today. J Natl Cancer Inst. 1981; 66: 1191-308.

2 Ames BN, Gold LS. The causes and prevention of cancer: gaining perspective. Environ Health Perspect. 1997; 105 Suppl 4: 865-73.

3 Pitot HC, Dragan YP. Chemical Carcinogenesis. In: Casarett and Doull's Toxicology: The Basic Science of Poisons, 6th ed. pp. 241-319, McGraw-Hill, New York, 2001.

4 IARC Working Group. IARC Monographs on the Evaluation of Carcinogenic Risks to Humans, vol. 56. Lyon, France: IARC; 1993.

5 Sugimura T. Overview of carcinogenic heterocyclic amines. Mutat Res. 1997; 376: 211-9.

6 Kawanishi S, Hiraku Y. Oxidative and nitrative DNA damage as biomarker for carcinogenesis with special reference to inflammation. Antioxid Redox Signal. 2006; 8: 1047-58.

7 Dijkwel PA, Wenink PW. Structural integrity of the nuclear matrix: differential effects of thiol agents and metal chelators. J Cell Sci. 1986; 84: 53-67.

8 Saucier MA, Wang X, Re RN, Brown J, Bryan SE. Effects of ionic strength on endogenous nuclease activity in chelated and nonchelated chromatin. J Inorg Biochem. 1991; 41: 117-24.

9 Overvad K, Wang DY, Olsen J, Allen DS, Thorling EB, Bulbrook RD, Hayward JL. Copper in human mammary carcinogenesis: a case-cohort study. Am J Epidemiol. 1993; 137: 409-14.

10 Hems G. The contributions of diet and childbearing to breast-cancer rates. Br J Cancer. 1978; 37: 974-82.

11 Chow WH, Gridley G, McLaughlin JK, Mandel JS, Wacholder S, Blot WJ, Niwa S, Fraumeni JF, Jr. Pro- tein intake and risk of renal cell cancer. J Natl Cancer Inst. 1994; 86: 1131-9.

12 Youngman LD, Campbell TC. The sustained development of preneoplastic lesions depends on high protein intake. Nutr Cancer. 1992; 18: 131-42.

13 Fukagawa NK, Galbraith RA. Advancing age and other factors influencing the balance between amino acid requirements and toxicity. J Nutr. 2004; 134: 1569S-74S

14 Davis AJ, Austic RE. Dietary threonine imbalance alters threonine dehydrogenase activity in isolated hepatic mitochondria of chicks and rats. J Nutr. 1994; 124: 1667-77.

15 Hiraku Y, Sugimoto J, Yamaguchi T, Kawanishi S. Oxidative DNA damage induced by aminoacetone, an amino acid metabolite. Arch Biochem Biophys. 1999; 365: 62-70.

16 Boyland E, Watson G. 3-Hydroxyanthranilic acid, a carcinogen produced by endogenous metabolism. Nature. 1956; 177: 837-8.

17 Bryan GT, Brown RR, Price JM. Mouse bladder carcinogenicity of certain tryptophan metabolites and other aromatic nitrogen compounds suspended in cholesterol. Cancer Res. 1964; 24: 596-602.

18 Abul-Fadl MA, Khalafallah AS. Studies on the urinary excretion of certain tryptophan metabolites in bilharziasis and its possible relation to bladder cancer in Egypt. Br J Cancer. 1961; 15: 479-82.

19 Bryan GT. The role of urinary tryptophan metabolites in the etiology of bladder cancer. Am J Clin Nutr. 1971; 24: 841-7.

20 Ehrhart H, Ried W, Benoit W, Dorfler H. Studies on experimental leukemias (VII). Adenocarcinomas, sarcomas and leukemias in mice following subcutaneous injections of 3-hydroxykynurenine. Z Krebsforsch. 1968; 71: 1-6.

21 Kuznezova LE. Mutagenic effect of 3-hydroxykynurenine and 3-hydroxyanthranilic acid. Nature. 1969; 222: 484-5.

22 Hiraku Y, Inoue S, Oikawa S, Yamamoto K, Tada S, Nishino K, Kawanishi S. Metal-mediated oxidative damage to cellular and isolated DNA by certain tryptophan metabolites. Carcinogenesis. 1995; 16: 349-56.

23 Laberge C, Lescault A, Tanguay RM. Hereditary tyrosinemias (type I): a new vista on tyrosine toxicity and cancer. Adv Exp Med Biol. 1986; 206: 209-21.

24 Rauschenbach MO, Zharova EI, Sergeeva TI, Ivanova VD, Probatova NA. Blastomogenic activity of $p$ hydroxyphenyllactic acid in mice. Cancer Res. 1975; 35: 577-85.

25 Weinberg AG, Mize CE, Worthen HG. The occurrence of hepatoma in the chronic form of hereditary tyrosinemia. J Pediatr. 1976; 88: 434-8.

26 Vogel A, van Den Berg IE, Al-Dhalimy M, Groopman J, Ou CN, Ryabinina O, Iordanov MS, Finegold M, Grompe M. Chronic liver disease in murine hereditary tyrosinemia type 1 induces resistance to cell death. Hepatology. 2004; 39: 433-43.

27 Glatt H. Endogenous mutagens derived from amino acids. Mutat Res. 1990; 238: 235-43. 
28 Hiraku Y, Yamasaki M, Kawanishi S. Oxidative DNA damage induced by homogentisic acid, a tyrosine metabolite. FEBS Lett. 1998; 432: 13-6.

29 von Studnitz W. Urinary excretion of aminoacetone following administration of L-threonine in man. Scand J Clin Lab Invest. 1967; 20: 29-32.

30 Cascino A, Muscaritoli M, Cangiano C, Conversano L, Laviano A, Ariemma S, Meguid MM, Rossi Fanelli F. Plasma amino acid imbalance in patients with lung and breast cancer. Anticancer Res. 1995; 15: 507-10.

31 Scioscia KA, Snyderman CH, Wagner R. Altered serum amino acid profiles in head and neck cancer. Nutr Cancer. 1998; 30: 144-7.

32 Pisani W, Bonzanino A, Franco G. The aminoacetone in neoplastic tissues. Boll Soc Ital Biol Sper. 1966; 42: 399-402.

33 Felton JS, Knize MG, Wood C, Wuebbles BJ, Healy SK, Stuermer DH, Bjeldanes LF, Kimble BJ, Hatch FT. Isolation and characterization of new mutagens from fried ground beef. Carcinogenesis. 1984; 5: 95-102.

34 Fay LB, Turesky RJ. Electron impact and fast atom bombardment mass spectrometric analysis of the foodborne carcinogens 2-amino-3-methylimidazo [4,5- $f]$ quinoline, 2-amino-3,8-dimethylimidazo [4,5-f] quinoxaline and their metabolites. Biol Mass Spectrom. 1992; 21: 463-9.

35 Yamashita M, Wakabayashi K, Nagao M, Sato S, Yamaizumi Z, Takahashi M, Kinae N, Tomita I, Sugimura T. Detection of 2-amino-3-methylimidazo $[4,5-f]$ quinoline in cigarette smoke condensate. Jpn J Cancer Res. 1986; 77: 419-22.

36 Nagao M. A new approach to risk estimation of foodborne carcinogens-heterocyclic amines-based on molecular information. Mutat Res. 1999; 431: 3-12.

37 Wakata A, Oka N, Hiramoto K, Yoshioka A, Negishi $\mathrm{K}$, Wataya $\mathrm{Y}$, Hayatsu $\mathrm{H}$. DNA strand cleavage in vitro by 3-hydroxyamino-1-methyl-5 $H$-pyrido[4,3- $b$ ]-indole, a direct-acting mutagen formed in the metabolism of carcinogenic 3-amino-1-methyl-5H-pyrido[4,3- $b$ ]indole. Cancer Res. 1985; 45: 5867-71.

38 Wataya Y, Yamane K, Hiramoto K, Ohtsuka Y, Okubata Y, Negishi K, Hayatsu H. Generation of intracellular active oxygens in mouse FM3A cells by 3-hydroxyamino-1-methyl-5 $H$-pyrido[4,3- $b$ ]indole, the activated Trp-P-2. Jpn J Cancer Res. 1988; 79: 576-9.

39 Esumi H, Ohgaki H, Kohzen E, Takayama S, Sugimura $\mathrm{T}$. Induction of lymphoma in CDF1 mice by the food mutagen, 2-amino-1-methyl-6-phenylimidazo[4,5-b]pyridine. Jpn J Cancer Res. 1989; 80: 1176-8.

40 Ito N, Hasegawa R, Sano M, Tamano S, Esumi H, Takayama S, Sugimura T. A new colon and mammary carcinogen in cooked food, 2-amino-1-methyl-6phenylimidazo[4,5-b]pyridine (PhIP). Carcinogenesis. 1991; 12: 1503-6.

41 Ohta $\mathrm{T}$, Nakatsugi S, Watanabe K, Kawamori $\mathrm{T}$, Ishikawa F, Morotomi M, Sugie S, Toda T, Sugimura T, Wakabayashi K. Inhibitory effects of Bifidobacterium-fermented soy milk on 2-amino-1-methyl-6phenylimidazo[4,5- $b$ ]pyridine-induced rat mammary carcinogenesis, with a partial contribution of its compo- nent isoflavones. Carcinogenesis. 2000; 21: 937-41.

42 Fretland AJ, Devanaboyina US, Feng Y, Leff MA, Xiao GH, Webb SJ, Hein DW. Oral administration of 2amino-1-methyl-6-phenylimidazo[4,5-b]pyridine (PhIP) yields PhIP-DNA adducts but not tumors in male Syrian hamsters congenic at the $N$-acetyltransferase 2 (NAT2) locus. Toxicol Sci. 2001; 59: 226-30.

43 Takahashi S, Tamano S, Hirose M, Kimoto N, Ikeda Y, Sakakibara M, Tada M, Kadlubar FF, Ito N, Shirai T. Immunohistochemical demonstration of carcinogenDNA adducts in tissues of rats given 2-amino-1-methyl6-phenylimidazo[4,5-b]pyridine (PhIP): detection in paraffin-embedded sections and tissue distribution. Cancer Res. 1998; 58: 4307-13.

44 El-Bayoumy K, Chae YH, Rosa JG, Williams LK, Desai D, Amin S, Fiala E. The effects of 1-nitropyrene, 2amino-1-methyl-6-phenylimidazo[4,5-b]pyridine and 7,12-dimethylbenz[ $a$ ]anthracene on 8-hydroxy-2'-deoxyguanosine levels in the rat mammary gland and modulation by dietary 1,4-phenylenebis(methylene) selenocyanate. Cancer Lett. 2000; 151: 7-13.

45 Weisburger JH, Dolan L, Pittman B. Inhibition of PhIP mutagenicity by caffeine, lycopene, daidzein, and genistein. Mutat Res. 1998; 416: 125-8.

46 Murata M, Kawanishi S. Oxidation of 5'-site guanine at GG and GGG sequences induced by a metabolite of carcinogenic heterocyclic amine PhIP in the presence of $\mathrm{Cu}(\mathrm{II})$ and NADH. Carcinogenesis. 2002; 23: 855-60.

47 Ohgaki H, Hasegawa H, Suenaga M, Sato S, Takayama $\mathrm{S}$, Sugimura T. Carcinogenicity in mice of a mutagenic compound, 2-amino-3,8-dimethylimidazo[4,5-f]quinoxaline (MeIQx) from cooked foods. Carcinogenesis. 1987; 8: 665-8.

48 Dooley KL, Von Tungeln LS, Bucci T, Fu PP, Kadlubar FF. Comparative carcinogenicity of 4-aminobiphenyl and the food pyrolysates, Glu-P-1, IQ, PhIP, and MeIQx in the neonatal B6C3F1 male mouse. Cancer Lett. 1992; 62: 205-9.

49 Kato T, Ohgaki H, Hasegawa H, Sato S, Takayama S, Sugimura T. Carcinogenicity in rats of a mutagenic compound, 2-amino-3,8-dimethylimidazo[4,5- $f$ ]quinoxaline. Carcinogenesis. 1988; 9: 71-3.

50 Kushida H, Wakabayashi K, Sato H, Katami M, Kurosaka R, Nagao M. Dose-response study of MeIQx carcinogenicity in F344 male rats. Cancer Lett. 1994; 83: $31-5$.

51 Turesky RJ, Lang NP, Butler MA, Teitel CH, Kadlubar FF. Metabolic activation of carcinogenic heterocyclic aromatic amines by human liver and colon. Carcinogenesis. 1991; 12: 1839-45.

52 Yanagawa Y, Sawada M, Deguchi T, Gonzalez FJ, Kamataki T. Stable expression of human CYP1A2 and $\mathrm{N}$-acetyltransferases in Chinese hamster CHL cells: mutagenic activation of 2-amino-3-methylimidazo[4,5$f$ ]quinoline and 2-amino-3,8-dimethylimidazo[4,5- $f$ quinoxaline. Cancer Res. 1994; 54: 3422-7.

53 Snyderwine EG, Davis CD, Nouso K, Roller PP, Schut HA. ${ }^{32} \mathrm{P}$-postlabeling analysis of IQ, MeIQx and PhIP adducts formed in vitro in DNA and polynucleotides and found in vivo in hepatic DNA from IQ-, MeIQx- 
and PhIP-treated monkeys. Carcinogenesis. 1993; 14: 1389-95.

54 Hirose M, Futakuchi M, Tanaka H, Orita SI, Ito T, Miki T, Shirai T. Prevention by antioxidants of heterocyclic amine-induced carcinogenesis in a rat mediumterm liver bioassay: results of extended and combination treatment experiments. Eur J Cancer Prev. 1998; 7: 61-7.

55 Hirose M, Hasegawa R, Kimura J, Akagi K, Yoshida Y, Tanaka H, Miki T, Satoh T, Wakabayashi K, Ito N, et al. Inhibitory effects of 1-O-hexyl-2,3,5-trimethylhydroquinone (HTHQ), green tea catechins and other antioxidants on 2-amino-6-methyldipyrido[1,2-a:3',2'-d]imidazole (Glu-P-1)-induced rat hepatocarcinogenesis and dose-dependent inhibition by HTHQ of lesion induction by Glu-P-1 or 2-amino-3,8-dimethylimidazo[4,5-f]quinoxaline (MeIQx). Carcinogenesis. 1995; 16: 3049-55.

56 Kato T, Hasegawa R, Nakae D, Hirose M, Yaono M, Cui L, Kobayashi Y, Konishi Y, Ito N, Shirai T. Dosedependent induction of 8-hydroxyguanine and preneoplastic foci in rat liver by a food-derived carcinogen, 2-amino-3,8-dimethylimidazo[4,5- $f$ ]quinoxaline, at low dose levels. Jpn J Cancer Res. 1996; 87: 127-33.

57 Murata M, Kobayashi M, Kawanishi S. Mechanism of oxidative DNA damage induced by a heterocyclic amine, 2-amino-3,8-dimethylimidazo[4,5f]quinoxaline. Jpn J Cancer Res. 1999; 90: 268-75.

58 Sasagawa C, Muramatsu M, Matsushima T. Formation of direct mutagens from amino-imidazoazaarenes by nitrite treatment. Mutat Res. 1988; 203: 386.

59 Hirose M, Wakabayashi K, Grivas S, De Flora S, Arakawa N, Nagao M, Sugimura T. Formation of a nitro derivative of 2-amino-3,4-dimethylimidazo[4,5$f$ ]quinoline by photo-irradiation. Carcinogenesis. 1990; 11: 869-71.

60 Morrison LD, Eling TE, Josephy PD. Prostaglandin H synthase-dependent formation of the direct-acting mutagen 2-nitro-3-methylimidazo[4,5- $f$ ]quinoline (nitro-IQ) from IQ. Mutat Res. 1993; 302: 45-52.

61 Dirr A, Wild D. Synthesis and mutagenic activity of nitro-imidazoarenes. A study on the mechanism of the genotoxicity of heterocyclic arylamines and nitroarenes. Mutagenesis. 1988; 3: 147-52.

62 Asan E, Fasshauer I, Wild D, Henschler D. Heterocyclic aromatic amine-DNA-adducts in bacteria and mammalian cells detected by ${ }^{32} \mathrm{P}$-postlabeling analysis. Carcinogenesis. 1987; 8: 1589-93.

63 Graf U, Wild D, Wurgler FE. Genotoxicity of 2-amino3-methylimidazo [4,5-f]quinoline (IQ) and related compounds in Drosophila. Mutagenesis. 1992; 7: 145-9.

64 Sawada S, Daimon H, Asakura S, Kawaguchi T, Yamatsu K, Furihata C, Matsushima T. Cumulative effects of chromosome aberrations and sister chromatid exchanges in rat liver induced in vivo by heterocyclic amines. Carcinogenesis. 1994; 15: 285-90.

65 Murata M, Kobayashi M, Kawanishi S. Nonenzymatic reduction of nitro derivative of a heterocyclic amine IQ by $\mathrm{NADH}$ and $\mathrm{Cu}(\mathrm{II})$ leads to oxidative DNA damage. Biochemistry. 1999; 38: 7624-9.
66 World Cancer Research Fund and American Institute for Cancer Research. Carbohydrate. In: Food, Nutrition and the Prevention of Cancer: a global perspective. Washington D. C.: American Institute for Cancer Research; 376-83, 1997.

67 Dandona P, Thusu K, Cook S, Snyder B, Makowski J, Armstrong D, Nicotera T. Oxidative damage to DNA in diabetes mellitus. Lancet. 1996; 347: 444-5.

68 Murata M, Mizutani M, Oikawa S, Hiraku Y, Kawanishi S. Oxidative DNA damage by hyperglycemia-related aldehydes and its marked enhancement by hydrogen peroxide. FEBS Lett. 2003; 554: 138-42.

69 IARC Working Group. Alcohol drinking. In: IARC Monographs on the Evaluation of Carcinogenic Risks to Humans, vol. 44. Lyon, France: IARC; 1988.

70 IARC. World Cancer Report. Lyon: IARC Press; 2003.

71 IARC Working Group. Acetoaldehyde. In: IARC Monographs on the Evaluation of Carcinogenic Risks to Humans, vol .71. pp. 319-36, Lyon, France: IARC; 1999.

72 Brooks PJ, Theruvathu JA. DNA adducts from acetaldehyde: implications for alcohol-related carcinogenesis. Alcohol. 2005; 35: 187-93.

73 Krokan H, Grafstrom RC, Sundqvist K, Esterbauer H, Harris CC. Cytotoxicity, thiol depletion and inhibition of $O^{6}$-methylguanine-DNA methyltransferase by various aldehydes in cultured human bronchial fibroblasts. Carcinogenesis. 1985; 6: 1755-9.

74 Wilson DM, 3rd, Tentler JJ, Carney JP, Wilson TM, Kelley MR. Acute ethanol exposure suppresses the repair of $O^{6}$-methylguanine DNA lesions in castrated adult male rats. Alcohol Clin Exp Res. 1994; 18: 1267-71.

75 Dey A, Cederbaum AI. Alcohol and oxidative liver injury. Hepatology. 2006; 43: S63-74.

76 Seitz HK, Stickel F. Risk factors and mechanisms of hepatocarcinogenesis with special emphasis on alcohol and oxidative stress. Biol Chem. 2006; 387: 349-60.

77 Kaneko T, Tahara S, Takabayashi F, Harada N. Suppression of 8-oxo-2'-deoxyguanosine formation and carcinogenesis induced by $\mathrm{N}$-nitrosobis (2-oxopropyl)amine in hamsters by esculetin and esculin. Free Radic Res. 2004; 38: 839-46.

78 Nair J, Gansauge F, Beger H, Dolara P, Winde G, Bartsch H. Increased etheno-DNA adducts in affected tissues of patients suffering from Crohn's disease, ulcerative colitis, and chronic pancreatitis. Antioxid Redox Signal. 2006; 8: 1003-10.

79 Mori Y, Koide A, Kobayashi Y, Morimura K, Kaneko M, Fukushima S. Effect of ethanol treatment on metabolic activation and detoxification of esophagus carcinogenic $N$-nitrosamines in rat liver. Mutagenesis. 2002; 17: 251-6.

80 Lofroth G, Gejvall T. Diethyl pyrocarbonate: formation of urethan in treated beverages. Science. 1971; 174: 1248-50.

81 Ough CS. Ethylcarbamate in fermented beverages and foods. I. Naturally occurring ethylcarbamate. J Agric Food Chem. 1976; 24: 323-8

82 Canas BJ, Havery DC, Robinson LR, Sullivan MP, Joe 
FL, Jr., Diachenko GW. Ethyl carbamate levels in selected fermented foods and beverages. J Assoc Off Anal Chem. 1989; 72: 873-6.

83 Miller JA, Miller EC. The metabolic activation and nucleic acid adducts of naturally-occurring carcinogens: recent results with ethyl carbamate and the spice flavors safrole and estragole. Br J Cancer. 1983; 48: 1-15.

84 Mori I, Yasuhara K, Hayashi SM, Nonoyama T, Nomura T, Mitsumori K. Carcinogen dose-dependent variation in the transgene mutation spectrum in urethane-induced lung tumors in transgenic mice carrying the human prototype c-Ha-ras gene. Cancer Lett. 2000; 153: 199-209.

85 IARC Working Group. Urethane. In: IARC Monographs on the Evaluation of Carcinogenic Risk of Chemicals to Human, vol. 7. pp. 111-40, Lyon, France: IARC; 1974.

86 Simmon VF. In vitro mutagenicity assays of chemical carcinogens and related compounds with Salmonella typhimurium. J Natl Cancer Inst. 1979; 62: 893-9.

87 Scherer E, Winterwerp H, Emmelot P. Modification of DNA and metabolism of ethyl carbamate in vivo: formation of 7-(2-oxoethyl)guanine and its sensitive determination by reductive tritiation using ${ }^{3} \mathrm{H}$-sodium borohydride. IARC Sci Publ. 1986; 109-25.

88 Park KK, Liem A, Stewart BC, Miller JA. Vinyl carbamate epoxide, a major strong electrophilic, mutagenic and carcinogenic metabolite of vinyl carbamate and ethyl carbamate (urethane). Carcinogenesis. 1993; 14: 441-50.

89 Bartsch H, Barbin A, Marion MJ, Nair J, Guichard Y. Formation, detection, and role in carcinogenesis of ethenobases in DNA. Drug Metab Rev. 1994; 26: 349-71.

90 Ioannou YM, Sanders JM, Matthews HB. Methyl carbamate. Species-dependent variations in metabolism and clearance in rats and mice. Drug Metab Dispos. 1988; 16: 435-40.

91 Sakano K, Oikawa S, Hiraku Y, Kawanishi S. Metabolism of carcinogenic urethane to nitric oxide is involved in oxidative DNA damage. Free Radic Biol Med. 2002; 33: 703-14.

92 Knight DC, Eden JA. A review of the clinical effects of phytoestrogens. Obstet Gynecol. 1996; 87: 897-904.

93 Nagata C, Takatsuka N, Kawakami N, Shimizu H. A prospective cohort study of soy product intake and stomach cancer death. Br J Cancer. 2002; 87: 31-6.

94 Skibola CF, Smith MT. Potential health impacts of excessive flavonoid intake. Free Radic Biol Med. 2000; 29: 375-83.

95 Newbold RR, Banks EP, Bullock B, Jefferson WN. Uterine adenocarcinoma in mice treated neonatally with genistein. Cancer Res. 2001; 61: 4325-8.

96 Thigpen JE, Locklear J, Haseman JK, Saunders H, Grant MF, Forsythe DB. Effects of the dietary phytoestrogens daidzein and genistein on the incidence of vulvar carcinomas in 129/J mice. Cancer Detect Prev. 2001; 25: 527-32.

97 Allred CD, Allred KF, Ju YH, Virant SM, Helferich WG. Soy diets containing varying amounts of genistein stimulate growth of estrogen-dependent (MCF-7) tumors in a dose-dependent manner. Cancer Res. 2001; 61: 5045-50.

98 Rao CV, Wang CX, Simi B, Lubet R, Kelloff G, Steele V, Reddy BS. Enhancement of experimental colon cancer by genistein. Cancer Res. 1997; 57: 3717-22.

99 Murata M, Midorikawa K, Koh M, Umezawa K, Kawanishi S. Genistein and daidzein induce cell proliferation and their metabolites cause oxidative DNA damage in relation to isoflavone-induced cancer of estrogen-sensitive organs. Biochemistry. 2004; 43: 2569-77.

100 Soto AM, Sonnenschein C, Chung KL, Fernandez MF, Olea N, Serrano FO. The E-SCREEN assay as a tool to identify estrogens: an update on estrogenic environmental pollutants. Environ Health Perspect. 1995; 103 Suppl 7: 113-22.

101 Hiraku Y, Yamashita N, Nishiguchi M, Kawanishi S. Catechol estrogens induce oxidative DNA damage and estradiol enhances cell proliferation. Int J Cancer. 2001; 92: 333-7.

102 Oikawa S, Ito T, Iwayama M, Kawanishi S. Radical production and DNA damage induced by carcinogenic 4-hydrazinobenzoic acid, an ingredient of mushroom Agaricus bisporus. Free Radic Res. 2006; 40: 31-9.

103 Tajima K, Tominaga S. Dietary habits and gastro-intestinal cancers: a comparative case-control study of stomach and large intestinal cancers in Nagoya, Japan. Jpn J Cancer Res. 1985; 76: 705-16.

104 Buiatti E, Palli D, Decarli A, Amadori D, Avellini C, Bianchi S, Biserni R, Cipriani F, Cocco P, Giacosa A, et al. A case-control study of gastric cancer and diet in Italy. Int J Cancer. 1989; 44: 611-6.

105 Alpha-Tocopherol Beta Carotene Cancer Prevention Study Group. The effect of vitamin E and beta carotene on the incidence of lung cancer and other cancers in male smokers. N Engl J Med. 1994; 330: 1029-35.

106 Omenn GS, Goodman GE, Thornquist MD, Balmes J, Cullen MR, Glass A, Keogh JP, Meyskens FL, Valanis B, Williams JH, Barnhart S, Hammar S. Effects of a combination of beta carotene and vitamin A on lung cancer and cardiovascular disease. N Engl J Med. 1996; 334: 1150-5.

107 Kawanishi S, Oikawa S, Murata M. Evaluation for safety of antioxidant chemopreventive agents. Antioxid Redox Signal. 2005; 7: 1728-39.

108 Murata M, Kawanishi S. Oxidative DNA damage by vitamin $\mathrm{A}$ and its derivative via superoxide generation. $\mathrm{J}$ Biol Chem. 2000; 275: 2003-8.

109 Yamashita N, Murata M, Inoue S, Burkitt MJ, Milne L, Kawanishi S. Alpha-tocopherol induces oxidative damage to DNA in the presence of copper(II) ions. Chem Res Toxicol. 1998; 11: 855-62.

110 IARC Working Group. Coffee. In: IARC Monographs on the Evaluation of Carcinogenic Risks to Humans, vol.51. pp. 41-197, Lyon, France: IARC; 1991.

111 IARC Working Group. In: IARC Monographs on the Evaluation of Carcinogenic Risks to Humans, vol.56. pp. 115-34, Lyon, France: IARC; 1993.

112 Inoue S, Ito K, Yamamoto K, Kawanishi S. Caffeic acid 
causes metal-dependent damage to cellular and isolated DNA through $\mathrm{H}_{2} \mathrm{O}_{2}$ formation. Carcinogenesis. 1992; 13: $1497-502$.

113 Zhang Y, Talalay P. Anticarcinogenic activities of organic isothiocyanates: chemistry and mechanisms. Cancer Res. 1994; 54: 1976s-81s.

114 Staretz ME, Foiles PG, Miglietta LM, Hecht SS. Evidence for an important role of DNA pyridyloxobutylation in rat lung carcinogenesis by 4-(methylnitrosamino)-1-(3-pyridyl)-1-butanone: effects of dose and phenethyl isothiocyanate. Cancer Res. 1997; 57: 259-66.

115 Sugie S, Yoshimi N, Okumara A, Tanaka T, Mori H. Modifying effects of benzyl isothiocyanate and benzyl thiocyanate on DNA synthesis in primary cultures of rat hepatocytes. Carcinogenesis. 1993; 14: 281-3.

116 Zhang Y, Kensler TW, Cho CG, Posner GH, Talalay P. Anticarcinogenic activities of sulforaphane and structurally related synthetic norbornyl isothiocyanates. Proc Natl Acad Sci USA. 1994; 91: 3147-50.

117 National Toxicology Program. Technical Report, Carcinogenesis Bioassay of Allyl isothiocyanate in F344/N Rats and B6C3F1 Mice, NTP TR-234, NIH Publication No. 83-144238. 1982.

118 Hirose M, Yamaguchi T, Kimoto N, Ogawa K, Futakuchi M, Sano M, Shirai T. Strong promoting activity of phenylethyl isothiocyanate and benzyl isothiocyanate on urinary bladder carcinogenesis in F344 male rats. Int J Cancer. 1998; 77: 773-7.

119 Lubet RA, Steele VE, Eto I, Juliana MM, Kelloff GJ, Grubbs CJ. Chemopreventive efficacy of anethole trithione, $N$-acetyl-L-cysteine, miconazole and phenethylisothiocyanate in the DMBA-induced rat mammary cancer model. Int J Cancer. 1997; 72: 95-101.

120 Murata M, Yamashita N, Inoue S, Kawanishi S. Mechanism of oxidative DNA damage induced by carcinogenic allyl isothiocyanate. Free Radic Biol Med. 2000; 28: 797-805.

121 Morimitsu Y, Nakagawa Y, Hayashi K, Fujii H, Kumagai T, Nakamura Y, Osawa T, Horio F, Itoh K, Iida K, Yamamoto M, Uchida K. A sulforaphane analogue that potently activates the Nrf2-dependent detoxification pathway. J Biol Chem. 2002; 277: 3456-63.

122 McWalter GK, Higgins LG, McLellan LI, Henderson CJ, Song L, Thornalley PJ, Itoh K, Yamamoto M, Hayes JD. Transcription factor Nrf2 is essential for induction of $\mathrm{NAD}(\mathrm{P}) \mathrm{H}$ :quinone oxidoreductase 1, glutathione $S$-transferases, and glutamate cysteine ligase by broccoli seeds and isothiocyanates. J Nutr. 2004; 134: 3499S-506S.

123 Kurokawa Y, Hayashi Y, Maekawa A, Takahashi M, Kokubo T, Odashima S. Carcinogenicity of potassium bromate administered orally to F344 rats. J Natl Cancer
Inst. 1983; 71: 965-72.

124 Murata M, Bansho Y, Inoue S, Ito K, Ohnishi S, Midorikawa K, Kawanishi S. Requirement of glutathione and cysteine in guanine-specific oxidation of DNA by carcinogenic potassium bromate. Chem Res Toxicol. 2001; 14: 678-85.

125 Kawanishi S, Oikawa S, Murata M, Tsukitome H, Saito I. Site-specific oxidation at GG and GGG sequences in double-stranded DNA by benzoyl peroxide as a tumor promoter. Biochemistry. 1999; 38: 16733-9.

126 Hussain SP, Hofseth LJ, Harris CC. Radical causes of cancer. Nat Rev Cancer. 2003; 3: 276-85.

127 Evans MD, Dizdaroglu M, Cooke MS. Oxidative DNA damage and disease: induction, repair and significance. Mutat Res. 2004; 567: 1-61.

128 Kawanishi S, Hiraku Y, Oikawa S. Mechanism of guanine-specific DNA damage by oxidative stress and its role in carcinogenesis and aging. Mutat Res. 2001; 488: $65-76$.

129 Burrows CJ, Muller JG. Oxidative nucleobase modifications leading to strand scission. Chem Rev. 1998; 98: 1109-51.

130 Wiseman H, Halliwell B. Damage to DNA by reactive oxygen and nitrogen species: role in inflammatory disease and progression to cancer. Biochem J. 1996; 313 (Pt 1): 17-29.

131 Steenken S, Jovanovic S. How easily oxidizable is DNA? One-electron reduction potentials of adenosine and guanosine radicals in aqueous solution. $\mathrm{J}$ Am Chem Soc. 1997; 119: 617-8.

132 Shibutani S, Takeshita M, Grollman AP. Insertion of specific bases during DNA synthesis past the oxidationdamaged base 8-oxodG. Nature. 1991; 349: 431-4.

133 Bruner SD, Norman DP, Verdine GL. Structural basis for recognition and repair of the endogenous mutagen 8oxoguanine in DNA. Nature. 2000; 403: 859-66.

134 Henderson PT, Delaney JC, Gu F, Tannenbaum SR, Essigmann JM. Oxidation of 7,8-dihydro-8-oxoguanine affords lesions that are potent sources of replication errors in vivo. Biochemistry. 2002; 41: 914-21.

135 Neeley WL, Delaney JC, Henderson PT, Essigmann JM. In vivo bypass efficiencies and mutational signatures of the guanine oxidation products 2-aminoimidazolone and 5-guanidino-4-nitroimidazole. J Biol Chem. 2004; 279: 43568-73.

136 Kino K, Saito I, Sugiyama H. Product analysis of GGspecific photooxidation of DNA via electron transfer: 2aminoimidazolone as a major guanine oxidation product. J Am Chem Soc. 1998; 120: 7373-4.

137 Singh R, Farmer PB. Liquid chromatography-electrospray ionization-mass spectrometry: the future of DNA adduct detection. Carcinogenesis. 2006; 27: 178-96. 